\title{
PLANNING THE FUTURE OF THE INTERNATIONAL DECADE OF OCEAN EXPLORATION
}

The United States programme for the International Decade of Ocean Exploration (IDOE) will end as scheduled in 1980. Plans are now underway to design the ocean research programme that will follow the IDOE. The goal will be to identify promising directions for marine research, their potential contributions to national ocean interests over the next five to ten years, and the management approach most appropriate for carrying out these programmes.

The basis for this planning effort will be four workshops in each of the major oceanographic disciplines, physical, biological, chemical and geological. A final workshop, planned and organized by the National Academy of Sciences, will bring together the recommendations from these workshops and report them to the National Science Foundation in late 1977.

The Office for the IDOE invites the interest and participation of the scientific community in planning for the post-1980 programme. Comments, recommendations, and requests for additional details may be sent to:

Head, Office for the International Decade of Ocean Exploration, National Science Foundation, Washington, D.C. 20550.

These comments and suggestions will be available as part of the background for these planning activities. 